\title{
Extreme dust storm over the eastern Mediterranean in September 2015: satellite, lidar, and surface observations in the Cyprus region
}

\author{
Rodanthi-Elisavet Mamouri ${ }^{1,2}$, Albert Ansmann ${ }^{3}$, Argyro Nisantzi ${ }^{1}$, Stavros Solomos $^{2}$, George Kallos ${ }^{4}$, and Diofantos \\ G. Hadjimitsis ${ }^{1}$ \\ ${ }^{1}$ Cyprus University of Technology, Department of Civil Engineering and Geomatics, Limassol, Cyprus \\ ${ }^{2}$ Institute for Astronomy, Astrophysics, Space Applications and Remote Sensing, \\ National Observatory of Athens, Athens, Greece \\ ${ }^{3}$ Leibniz Institute for Tropospheric Research, Leipzig, Germany \\ ${ }^{4}$ School of Physics, Division of Environment and Meteorology, University of Athens, Athens, Greece \\ Correspondence to: Rodanthi-Elisavet Mamouri (rodanthi.mamouri@cut.ac.cy)
}

Received: 25 April 2016 - Published in Atmos. Chem. Phys. Discuss.: 9 May 2016

Revised: 10 October 2016 - Accepted: 12 October 2016 - Published: 4 November 2016

\begin{abstract}
A record-breaking dust storm originating from desert regions in northern Syria and Iraq occurred over the eastern Mediterranean in September 2015. In this contribution of a series of two articles (part 1, observations; part 2, atmospheric modeling), we provide a comprehensive overview of the aerosol conditions during this extreme dust outbreak in the Cyprus region. These observations are based on satellite observations (MODIS, moderate resolution imaging spectroradiometer) of aerosol optical thickness (AOT) and Ångström exponent, surface particle mass $\left(\mathrm{PM}_{10}\right)$ concentrations measured at four sites in Cyprus, visibility observations at three airports in southern Cyprus and corresponding conversion products (particle extinction coefficient, dust mass concentrations), EARLINET (European Aerosol Research Lidar Network) lidar observations of dust vertical layering over Limassol, particle optical properties (backscatter, extinction, lidar ratio, linear depolarization ratio), and derived profiles of dust mass concentrations. Maximum $550 \mathrm{~nm}$ AOT exceeded values of 5.0, according to MODIS, and the mass loads were correspondingly $>10 \mathrm{~g} \mathrm{~m}^{-2}$ over Larnaca and Limassol during the passage of an extremely dense dust front on 8 September 2015. Hourly mean $\mathrm{PM}_{10}$ values were close to $8000 \mathrm{\mu g} \mathrm{m}^{-3}$ and the observed meteorological optical range (visibility) was reduced to $300-750 \mathrm{~m}$ at Larnaca and Limassol. The visibility observations suggest peak values of the near-surface total suspended particle (TSP) extinction coefficients of $6000 \mathrm{Mm}^{-1}$ and thus TSP mass concentrations of $10000 \mathrm{~g} \mathrm{~m}^{-3}$. The Raman polarization lidar ob-
\end{abstract}

servations mainly indicated a double layer structure of the dust plumes (reaching to about $4 \mathrm{~km}$ height), pointing to at least two different dust source regions. Dust particle extinction coefficients $(532 \mathrm{~nm})$ already exceeded $1000 \mathrm{Mm}^{-1}$ and the mass concentrations reached $2000 \mu \mathrm{g} \mathrm{m}^{-3}$ in the elevated dust layers on 7 September, more than $12 \mathrm{~h}$ before the peak dust front on 8 September reached the Limassol lidar station around local noon. Typical Middle Eastern dust lidar ratios around $40 \mathrm{sr}$ were observed in the dense dust plumes. The particle depolarization ratio decreased from around 0.3 in the lofted dense dust layers to 0.2 at the end of the dust period (11 September), indicating an increasing impact of anthropogenic haze.

\section{Introduction}

On 7-11 September 2015, a record-breaking dust storm hit Cyprus. According to MODIS (moderate resolution imaging spectroradiometer), the aerosol optical thickness (AOT) exceeded 5.0 at $550 \mathrm{~nm}$ over large parts of the eastern Mediterranean. The dense dust clouds originated from Middle East deserts, mainly from northeastern Syria and northern Iraq. Such strong dust storms are rather seldom. Figure 1 provides an overview of AOT observed with MODIS over Limassol, Cyprus, from 2001 to 2015. Twelve extreme dust outbreaks reached Limassol in southern Cyprus within the 2001-2015 period. The strongest dust outbreaks were ob- 


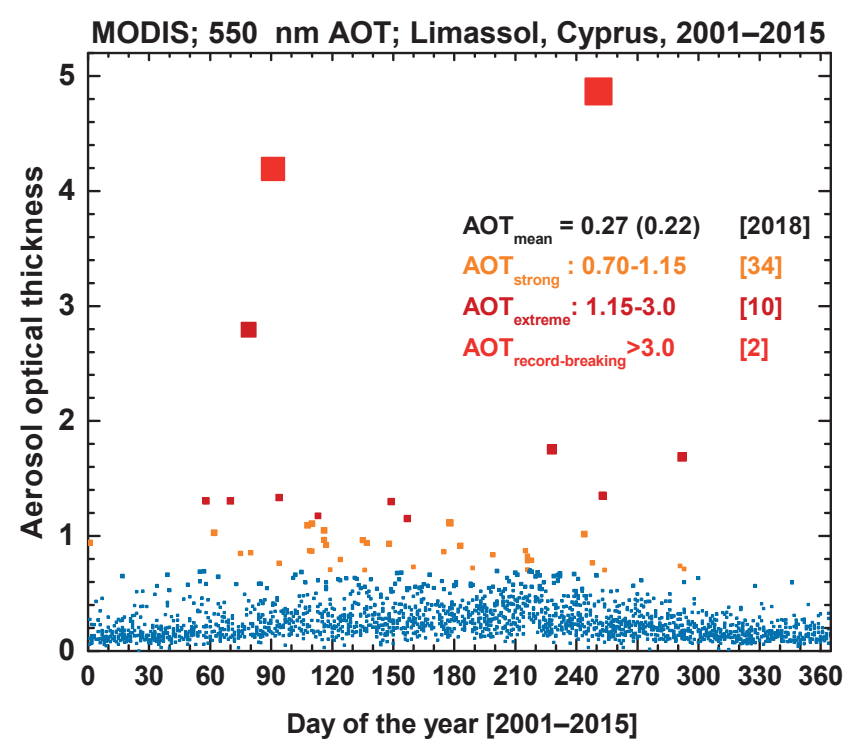

Figure 1. Seasonal distribution of $550 \mathrm{~nm}$ AOT at Limassol, based on 15 years of MODIS observations (http://lance-modis.eosdis. nasa.gov/, terra MODIS, 2001-2002, aqua MODIS, 2003-2015). The mean AOT for an area centered at Limassol with a $25 \mathrm{~km}$ radius is shown. Numbers (in black) indicate the 15 year mean AOT (M), the standard deviation ( $\mathrm{SD}$, in parentheses), and the total number of considered daily observations (in brackets). The numbers of strong dust events (AOT from $\mathrm{M}+2 \mathrm{SD}$ to $\mathrm{M}+4 \mathrm{SD}$ ), of extreme dust events (AOT from $\mathrm{M}+4 \mathrm{SD}$ to 3.0), and record-breaking dust events $($ AOT $>3$ ) are given in orange, dark red, and red, respectively. MODIS collection-6 data were used for the years 2005-2015 and collection-51 data for 2001-2004. More details to the MODIS data, including AOT retrieval uncertainties, are given in Sect. 2.2.

served on 1 April 2013 (AOT $>4.0$, Saharan dust storm) and 8 September 2015 (AOT > 5.0, Middle East desert dust storm). Extreme dust events, characterized by an AOT exceeding the climatological mean AOT by four standard deviations, occur, on average, 1-2 times per year for the given site in the Mediterranean. The AOT is most frequently lower than 1.5 during these events (Gkikas et al., 2016). An extended aerosol characteristics for the entire Mediterranean region and an extended literature survey is also given by Georgoulias et al. (2016).

Surprisingly, dust transport models widely failed to predict this record-breaking dust storm in September 2015 (http://sds-was.aemet.es/forecast-products/dust-forecasts/ compared-dust-forecasts). This fact and the enormous dust mass concentrations measured in Cyprus motivated us to investigate the underlying weather conditions that caused this huge dust outbreak. Extreme dust events provide a unique opportunity to learn more about known and established dust mobilizing mechanisms and to identify and explore new or not-well-parameterized dust emission processes. The dust storm was obviously linked to an extraordinary weather situation, with dust mobilization features on scales that were too small to be resolved by the used global and regional weather and dust transport models. We investigate this extreme dust event in detail by combining the available dust observations in the Cyprus area (presented in this article) with complex atmospheric modeling (Solomos et al., 2016). The occurrence of a haboob in northeastern Syria and northern Iraq was probably responsible for this unique dust outbreak. Haboobs are intense dust storms caused by strong thunderstorm activity, which are associated with density currents (Knippertz et al., 2007; Solomos et al., 2012), strong precipitation, and vigorous cold air downbursts reaching the ground and pushing huge amounts of dust and sand into the air.

The goal of this first article is to provide an overview of the available dust observations in the Cyprus region. We present time series of spaceborne observations (MODIS) of AOT for five sites in Cyprus, continuous particle mass concentration measurements $\left(\mathrm{PM}_{10}\right.$, mass concentration of particles with aerodynamic diameter smaller than $10 \mu \mathrm{m}$ ) at four stations, visibility observations from three airports in Cyprus, and lidar observations performed at Limassol. We are not aware of any report in the literature in which a severe, record-breaking dust storm has been discussed in such observational detail. The lidar measurements are especially highlighted in our study. The observed temporally and vertically resolved dust layering structures and the derived profiles of particle extinction coefficient and dust mass concentration provide indispensable information for dust transport simulation studies (presented in the second article). Comparison of modeled and lidar-derived dust profiles are of basic importance in modelbased investigations of the relationship between given meteorological conditions over the dust source regions, dust mobilization, and observed long-range dust transport features (Heinold et al., 2009, 2011; Müller et al., 2009).

Several long-term lidar studies of dust outbreaks towards the Mediterranean are available, but with the main focus on Saharan dust outbreaks (e.g., Amiridis et al., 2005; Mona et al., 2006, 2014; Papayannis et al., 2008; Papayannis et al., 2009). An extreme Saharan dust event with AOT up to 1.5 at $500 \mathrm{~nm}$ over southern Spain, observed with lidar, was discussed by Guerrero-Rascado et al. (2009). Another lidar study of an exceptionally strong dust outbreak towards Portugal with dust optical thickness up to 2.0 was presented by Preißler et al. (2011). The first lidar-based long-term study for the eastern Mediterranean, which includes Saharan as well as Middle Eastern desert dust outbreaks, was presented by Nisantzi et al. (2015), based on the Limassol lidar observations.

After the introduction, a brief description of the observation methods, data analysis, and measurement products is given in Sect. 2. The observations are presented in Sect. 3 and concluding remarks are given in Sect. 4. 


\section{Aerosol instrumentation and observational products}

\subsection{EARLINET lidar profiling of dust optical properties and mass concentration}

The lidar observations were conducted by the Cyprus University of Technology (CUT) at Limassol $\left(34.7^{\circ} \mathrm{N}, 33^{\circ} \mathrm{E}\right.$; $23 \mathrm{~m}$ above sea level, a.s.1.), Cyprus. The lidar station is part of the European Aerosol Research Lidar Network (EARLINET) (Pappalardo et al., 2014) and is equipped with a $532 \mathrm{~nm}$ Raman polarization lidar (nitrogen Raman channel at $607 \mathrm{~nm}$ ) (Mamouri et al., 2013; Mamouri and Ansmann, 2014; Nisantzi et al., 2015). The EARLINET site is combined with an Aerosol Robotic Network (AERONET) station (Holben et al., 1998; Nisantzi et al., 2014, 2015) and located in the city center of Limassol (see CUT-TEPAK site in the AERONET database; TEPAK stands for the Greek name TEchologiko PAnepistimio Kyprou). Unfortunately, the CUT-TEPAK AERONET photometer was not available from July to October 2015 for calibration reasons.

Details of the lidar data analysis regarding the retrieval of the particle linear depolarization ratio $\delta$, backscatter coefficient $\beta$, extinction coefficient $\sigma$, extinction-to-backscatter ratio (lidar ratio) $S$, and the separation of dust backscatter coefficient $\beta_{\mathrm{d}}$ and non-dust backscatter coefficient $\beta_{\text {nd }}$ are given by Tesche et al. (2009a, b), Mamouri et al. (2012, 2013), Mamouri and Ansmann (2014), and Nisantzi et al. (2014, 2015).

The dust mass concentration $M_{\mathrm{d}}$ is then obtained from the backscatter coefficients $\beta_{\mathrm{d}}$ by means of the equation

$M_{\mathrm{d}}=\rho_{\mathrm{d}} c_{\mathrm{v}, \mathrm{d}} \beta_{\mathrm{d}} S_{\mathrm{d}}$,

with the dust particle density $\rho_{\mathrm{d}}$, assumed to be $2.6 \mathrm{~g} \mathrm{~cm}^{-3}$ (Ansmann et al., 2012), the volume-to-extinction conversion factor $c_{\mathrm{v}, \mathrm{d}}=v_{\mathrm{d}} / \sigma_{\mathrm{d}}$, the dust volume concentration $v_{\mathrm{d}}$, and the dust lidar ratio $S_{\mathrm{d}}$.

By using a characteristic dust lidar ratio $S_{\mathrm{d}}$ (or even measured ones as during this dust storm), we convert the retrieved profiles of the backscatter coefficient $\beta_{\mathrm{d}}$ into respective profiles of dust extinction coefficient $\sigma_{\mathrm{d}}$. We use $S_{\mathrm{d}}=40 \mathrm{sr}$ for Middle Eastern desert dust (Mamouri et al., 2013). Then, the dust extinction profile is converted into the particle volume and mass concentration profiles $v_{\mathrm{d}}$ and $M_{\mathrm{d}}$, respectively, by using conversion factors from AERONET column observations during pure desert dust situations. Appropriate conversion factors were derived from extended studies during large dust field campaigns in Morocco, Cabo Verde, and Barbados (Mamouri and Ansmann, 2016). The average conversion factor $c_{\mathrm{v}, \mathrm{d}}$ is $0.64 \pm 0.06 \times 10^{-12} \mathrm{Mm}$.

The uncertainties in all the optical properties, conversion factors, and estimated microphysical properties are discussed by Tesche et al. (2009a, b); Gasteiger et al. (2011a, b); Ansmann et al. (2012); and Mamouri and Ansmann (2014). Relative uncertainties in the dust backscatter and extinction coefficients and lidar ratios are 10-20\% at dense dust condi- tions. In addition, considering a relative uncertainty of $10 \%$ in the assumed dust density $\rho_{\mathrm{d}}$ and of about $10 \%$ in the conversion factor $c_{\mathrm{v}, \mathrm{d}}$, we yield an overall relative uncertainty of $20-30 \%$ in the estimated dust mass concentrations.

\subsection{MODIS observations of AOT}

MODIS products are used to describe the dust load in the Cyprus region. For five sites we calculated the mean AOT at $550 \mathrm{~nm}$ wavelength and the mean Ångström exponent (for the 510-670 nm spectral range) from the available set of AOT data in areas within a $50 \mathrm{~km}$ radius around these cities. For Limassol, we also calculated the mean AOT for a $25 \mathrm{~km}$ radius. Only values that passed a quality check (QAC) are included in the averaging. These are level- 2 single pixel AOT $(550 \mathrm{~nm})$ measurements with a QAC flag of 3 and $>0$ over land and over the Mediterranean Sea, respectively. The maximum retrievable AOT is 5.0. In the MODIS database (https: //ladsweb.nascom.nasa.gov/data/search.html), all individual validated (pixel) AOT values are set to 5.0 for $\mathrm{AOT} \geq 5.0$. As will be discussed in Sect. 3, this was the case for several stations on 8 September 2015.

The uncertainty in the retrieved AOT is $0.05 \pm 0.15 \times$ AOT for $\mathrm{AOT} \leq 1.0$ (Levy et al., 2010, 2013). Our comparisons of the MODIS products with available AERONET observations at Agia Marina $(30 \mathrm{~km}$ west of Nicosia) corroborate this uncertainty for AOT $<1.0$. However, MODIS AOT values were systematically larger for AOT $>2.5$. We analyzed Limassol observations (1 April 2013, MODIS AOT of about 4.5, AERONET AOT of 3.2-3.6) and measurements over the AERONET station of the Weizmann Institute, Rehovot, Israel (9-10 September 2015, MODIS AOT of 3.8-3.9, AERONET AOT of 2.4-2.8). Overall, the AOT overestimation was in the range from 0.5 to 1.5 for AOT $(550 \mathrm{~nm})>2.5$.

\subsection{PM $_{10}$ observations of the Department of Labour Inspection of Cyprus}

Non-validated hourly mean surface observations of $\mathrm{PM}_{10}$ concentrations are published by the Air Quality Department of Cyprus (Department of Labour Inspection, DLI; http://www.airquality.dli.mlsi.gov.cy/). We checked the uncertainty in the non-validated hourly values by comparing quality-assured $24 \mathrm{~h} \mathrm{PM}_{10}$ values (gravimetric method, European standard; kindly provided by DLI; C. Savvides, personal communication, July 2016) with respective 24-h mean values calculated from the hourly mean non-validated data. Uncertainties of the order of $\pm 20-50 \%$ must be considered in the discussions of the observations in Sect. 3 as our analysis revealed. 

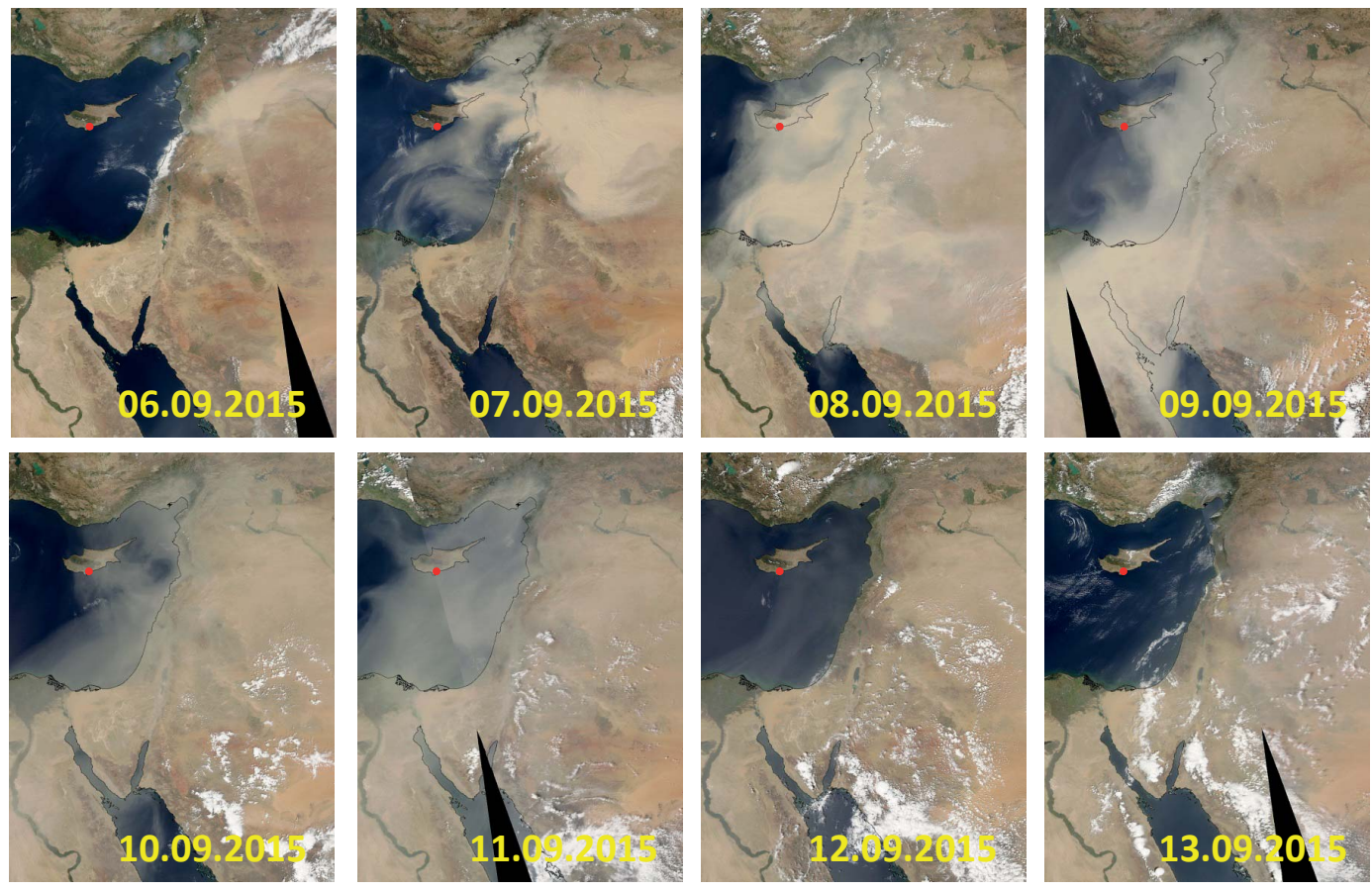

Figure 2. Dust outbreak towards Cyprus in September 2015 as seen from space (aqua-MODIS, 10:30-11:30 UTC overpasses, 13:3014:30 EEST, Eastern European Summer Time). Red points indicate Limassol.

\subsection{Visibility observations of the Department of Meteorology of Cyprus}

Another way to estimate the dust mass load at ground is based on observations of the so-called meteorological optical range (MOR) $r_{\text {vis }}$, better known as Koschmieder visibility (Koschmieder, 1924; Horvath and Noll, 1969; Horvath, 1971). We present visibility time series from three airports in Cyprus (Larnaca, Paphos, and Akrotiri, about $10 \mathrm{~km}$ southwest of the Limassol city center). The data are kindly provided by the Department of Meteorology, Cyprus (DoM; Filippos Tymvios, personal communication, June 2016). The visibility values are estimated by human observers which are carefully trained after the guidelines of the World Meteorological Organization. The uncertainty of the MOR estimation is of the order of $20-30 \%$ for $r_{\text {vis }}>1000 \mathrm{~m}$ up to $20 \mathrm{~km}$. For lower MOR, the uncertainty may be considerably higher.

The visibility $r_{\text {vis }}$ is linked to the particle extinction coefficient $\sigma$ for $500-550 \mathrm{~nm}$ (in the visible wavelength spectrum) by the relationship (e.g., Horvath and Noll, 1969; Horvath, 1971)

$\sigma=3.0 / r_{\mathrm{vis}} \times 10^{6}$

with $r_{\mathrm{vis}}$ in $\mathrm{m}$ and $\sigma$ in $\mathrm{Mm}^{-1}$. The AOT of 3.0 describes the attenuation of light along the horizontal distance with length $r_{\text {vis }}$. Equation (2) is based on the original Koschmieder formula. Koschmieder (1924) used an AOT of 3.9 which causes an apparent contrast of the object against the bright background of 0.02 . The AOT of 3.0 is related to the intuitive concept of visibility through the contrast threshold taken as 0.05 .

During the strong dust outbreak in September 2015, however, the visibility dropped to values of the order of 300$1000 \mathrm{~m}$, which corresponds to dust extinction coefficients of the order of $3000-10000 \mathrm{Mm}^{-1}$. At these conditions, contributions of marine and anthropogenic particles (including contributions by water uptake) to the total particle extinction coefficient can be neglected. Under clear air conditions, the extinction coefficient of urban haze at $500-550 \mathrm{~nm}$ is $50-150 \mathrm{Mm}^{-1}$ over Limassol (Nisantzi et al., 2015). A typical marine aerosol contribution to particle extinction is 50$100 \mathrm{Mm}^{-1}$ (Mamouri and Ansmann, 2016).

In order to compare the visibility observations and in situ $\mathrm{PM}_{10}$ mass concentrations, we convert the derived particle extinction coefficients $\sigma_{\mathrm{d}}$ into dust mass concentrations $M_{\mathrm{d}}$ by using the relationship (compare Eq. 1)

$M_{\mathrm{d}}=\rho_{\mathrm{d}} c_{\mathrm{v}, \mathrm{d}} \sigma_{\mathrm{d}}$,

with the volume-to-extinction dust conversion factor $c_{\mathrm{v}, \mathrm{d}}$ of $0.64 \pm 0.06 \times 10^{-12} \mathrm{Mm}$ and the dust particle density $\rho_{\mathrm{d}}$ of $2.6 \mathrm{~g} \mathrm{~cm}^{-3}$, as introduced in Sect. 2.1. The uncertainty mainly depends on the uncertainty in the visibility estimation. 


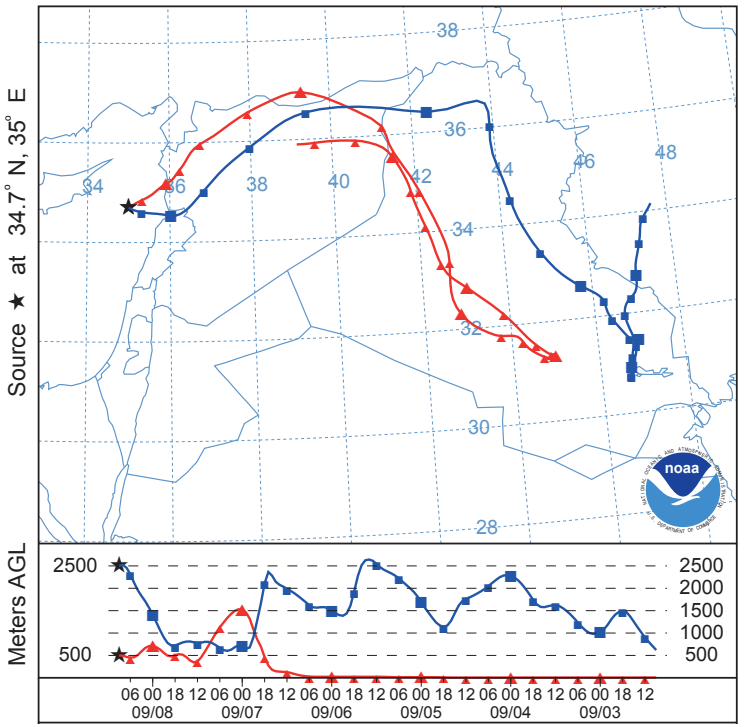

Figure 3. Six-day HYSPLIT backward trajectories arriving in the Cyprus region at $35^{\circ} \mathrm{E}$ (about $160 \mathrm{~km}$ east of the Limassol lidar station) at $500 \mathrm{~m}$ (red, lower dust layer) and $2500 \mathrm{~m}$ height (blue, upper dust layer) on 8 September 2015, 09:00 UTC (12:00 EEST).

\section{Results}

\subsection{Dust transport features: Horizontal and vertical dust distribution}

Figure 2 provides an overview of the enormous dust storm in the beginning of September 2015 as seen by MODIS. Optically dense dust plumes were advected from the east and reached Cyprus on 7 September 2015. Parts of the dust plumes were so dense that the dark surface of the Mediterranean Sea and eastern and southern parts of the island of Cyprus were no longer visible from space. The highest dust load was observed over Cyprus on 8 September 2015. On this day, the $550 \mathrm{~nm}$ AOT clearly exceeded 5 , as will be discussed in detail in the next subsection. Unfortunately, lidar observations were not possible on 8 September. We did not switch on the lidar on this day in order to avoid any potential damage of lidar optics and detection units. The dust amount slowly decreased and showed a second, much weaker maximum on 10-11 September. The Troodos Mountains (dark area in southwestern Cyprus) with maximum heights of up to $2000 \mathrm{~m}$ were always visible during the dust storm (even on 8 September, AOT $>5$ ). This indicates that the thickest dust layers crossed Cyprus at heights below $1500 \mathrm{~m}$ height. This conclusion is supported by the lidar observations on 7 , 9-11 September, described later in this section.

To provide a rough idea about the dust source regions and the main airflow during this dust event, Fig. 3 shows 6-day backward trajectories for 8 September 2015 (09:00 UTC). The arrival height of the red trajectory (500 $\mathrm{m}$ a.s.l.) is in the lower dust layer, which reached about $1.5 \mathrm{~km}$ height accord- ing to the Limassol lidar observations on 7 and 9 September. This is also clearly visible in the Nicosia radiosonde profiles of temperature and relative humidity $(\mathrm{RH})$ on 8 September (06:00 and 12:00 UTC launches) as will be discussed below. The arrival height of the blue trajectory $(2.5 \mathrm{~km})$ is in the upper dust layer (from 1.5 to $3.8 \mathrm{~km}$ as seen by the lidar on 7 and 9 September and indicated by the Nicosia radiosonde profiles on 8 September). The backward trajectories are calculated for a site in the Mediterranean Sea east of Cyprus $\left(34.7^{\circ} \mathrm{N}, 35^{\circ} \mathrm{E}\right)$. Here, the densest dust plumes occurred in the Cyprus area on 8 September 2015 according to Fig. 2. The HYSPLIT (HYbrid Single-Particle Lagrangian Integrated Trajectory, http://www.arl.noaa.gov/ HYSPLIT.php) model was used to calculate the backward trajectories (Stein et al., 2015). Dust from Middle East deserts were transported northwest towards northern Iraq and northeastern Syria, and then to the west towards Cyprus.

Figure 4 presents the Limassol lidar observations of the vertical dust layering observed from 7 to 11 September 2015 . We operated the lidar daily for 3-11 h, except on 8 September. Dust advection occurred in two to three pronounced, separated dust layers (below about 500-800 m height, and two layers with top heights of $1.5-1.7 \mathrm{~km}$ and $3.5-4.2 \mathrm{~km}$ height) on 7-9 September. A first thick dust layer crossed Cyprus on the evening of 7 September between 2 and $3.7 \mathrm{~km}$ height. We speculate that these layer structures also prevailed on 8 September. This is corroborated by the profiles of temperature and RH measured with radiosondes launched at Nicosia about $60 \mathrm{~km}$ northeast of Limassol on 8 September at 06:00 and 12:00 UTC.

Figure 5 depicts the dominating double layer dust structures in terms of dust mass concentration derived from the lidar observations on the evening of 7 September. The values reach $2000 \mu \mathrm{g} \mathrm{m}^{-3}$ below $1500 \mathrm{~m}$ height and $600 \mu \mathrm{g} \mathrm{m}^{-3}$ around $3 \mathrm{~km}$ height on 7 September 2015. The double layer structure of the dust plume is well reflected in the meteorological data measured with the Nicosia radiosonde on 8 September, 06:00 UTC, 2-3 $\mathrm{h}$ before the arrival of the main dust front. The changes in $\mathrm{RH}$ and potential temperature with height indicated different air masses and thus different dust source regions above and below about $1500 \mathrm{~m}$ height. The meteorological data also indicate that the dust layer was still lofted (base height at around $700 \mathrm{~m}$ above ground) on the morning of 8 September, at 06:00 UTC.

Similar dust layering structures were then observed with lidar a day later on 9 September 2015 (see Fig. 4), again in consistency with the temperature and humidity profiles of the Nicosia radiosonde (not shown). On the evening of 10 September, another elevated optically dense dust layer crossed the EARLINET lidar station. Finally, on 11 September, a more homogeneous and temporally constant layering was found. The main layer was now below $2 \mathrm{~km}$ height. However, traces of dust were detected up to $3-4 \mathrm{~km}$ height. On 12 September, the decrease in the AOT values derived 

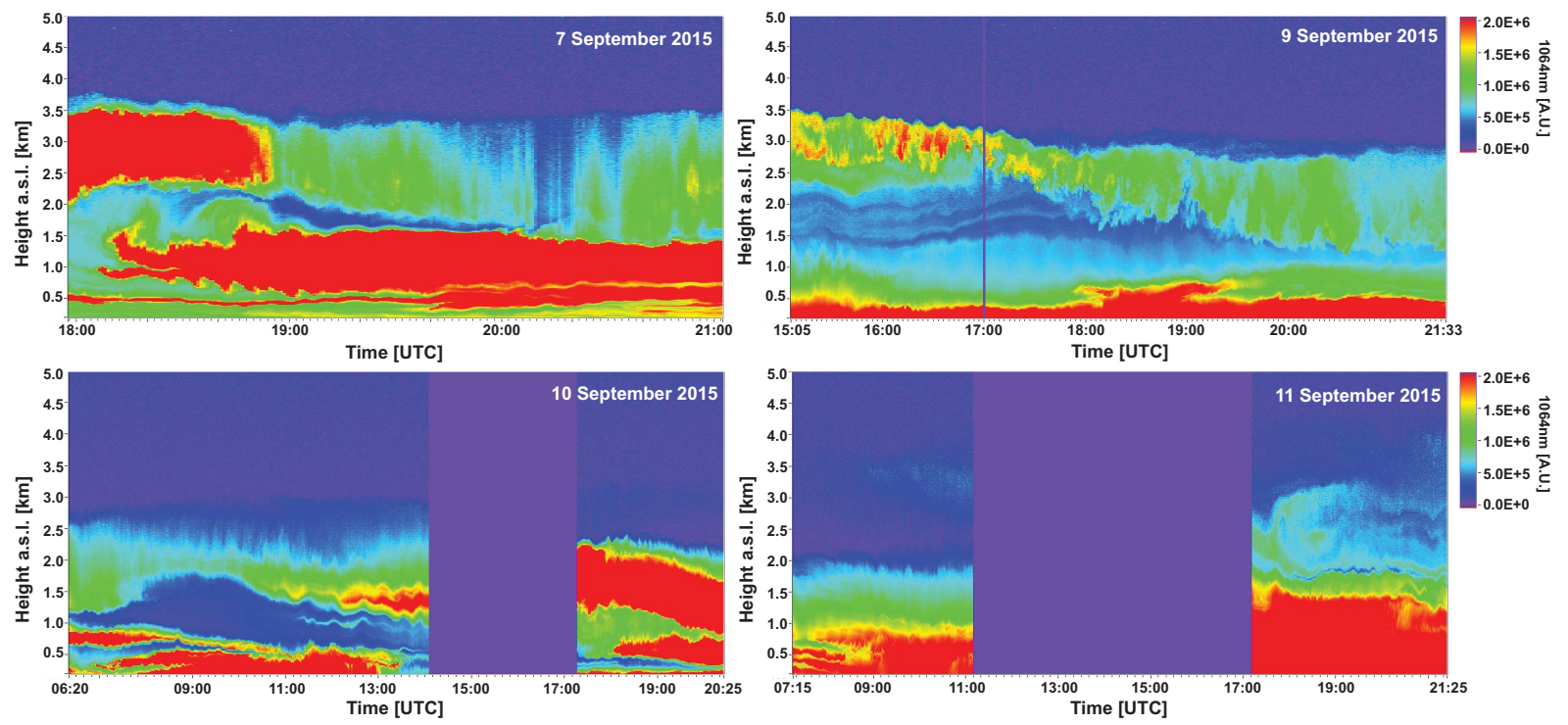

Figure 4. Desert dust layers observed with lidar over the EARLINET station of Limassol, Cyprus, on 7, 9, 10, and 11 September 2015. Range-corrected $1064 \mathrm{~nm}$ backscatter signals (in arbitrary units, A.U.) are shown. On 7-10 September, a double layer structure dominated with dust layers below about $1-1.7 \mathrm{~km}$ height and another layer reaching to $2.5-3.7 \mathrm{~km}$ height. Local time (EEST) is time in UTC plus $3 \mathrm{~h}$.

from lidar and MODIS observations indicated the end of the dust episode.

In Fig. 6, four photographs taken on 8 and 9 September 2015 from the roof of a high building (AERONET station) at Limassol to the south and north are presented. The left photographs show the situation during the phase with the heaviest dust load (8 September, around local noon). These pictures are in strong contrast to the photographs taken one day later, when the dust concentration was still high but the horizontal visibility increased to more than $10 \mathrm{~km}$.

The peak dust front reached Limassol at ground between 08:00 and 09:00 UTC on 8 September. The vertical gradients of temperature and $\mathrm{RH}$ were significantly different in the height ranges below and above $1.5 \mathrm{~km}$ height. According to the 12:00 UTC radiosonde, RH values increased from $10-15 \%$ at the surface to about $30 \%$ at the top of the lower layer in $1.5 \mathrm{~km}$ height and indicated well-mixed dust conditions in the Nicosia area. Similarly, the potential temperature was almost height independent and thus indicated favorable conditions for vertical mixing. In the upper layer from 1.5 to $3.8 \mathrm{~km}$ height, slightly stable conditions were observed.

By careful inspection of the pictures from 8 September in Fig. 6 (searching for different pronounced buildings and towers) we estimated the horizontal visibility to be 500$600 \mathrm{~m}$. The visibility measurements performed at three airports in Cyprus are discussed in the next subsection. A visibility of $500 \mathrm{~m}$ points to dust extinction coefficients of about $6000 \mathrm{Mm}^{-1}$ according to Eq. (2). If this extremely high extinction coefficient occurred at all heights up to $800 \mathrm{~m}$ or $1.5 \mathrm{~km}$, we would end up with AOTs of 4.8 and 9, respectively. These speculative values are in the range of AOTs in-

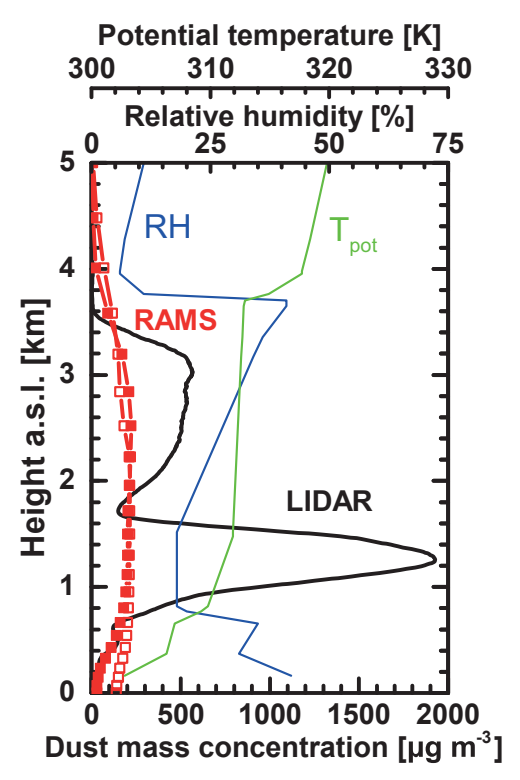

Figure 5. Mean dust mass concentration observed with lidar (thick solid black line) at Limassol on 7 September, 19:00-20:00 UTC, and dust profiles simulated with RAMS (normal run with $20 \mathrm{~km}$ horizontal resolution) for Limassol, on 7 September, 18:00 UTC (closed red squares) and 8 September, 09:00 UTC (open squares). Radiosonde observation (launched at the radiosonde station at Athalassa near Nicosia on 8 September 06:00 UTC) of height profiles of potential temperature ( $T_{\text {pot }}$, thin green curve) and relative humidity (RH, thin blue curve) are in good agreement with the double layer dust structures observed about $12 \mathrm{~h}$ earlier. The lofted dust layer from 1.7 to $3.6 \mathrm{~km}$ height was well mixed. 

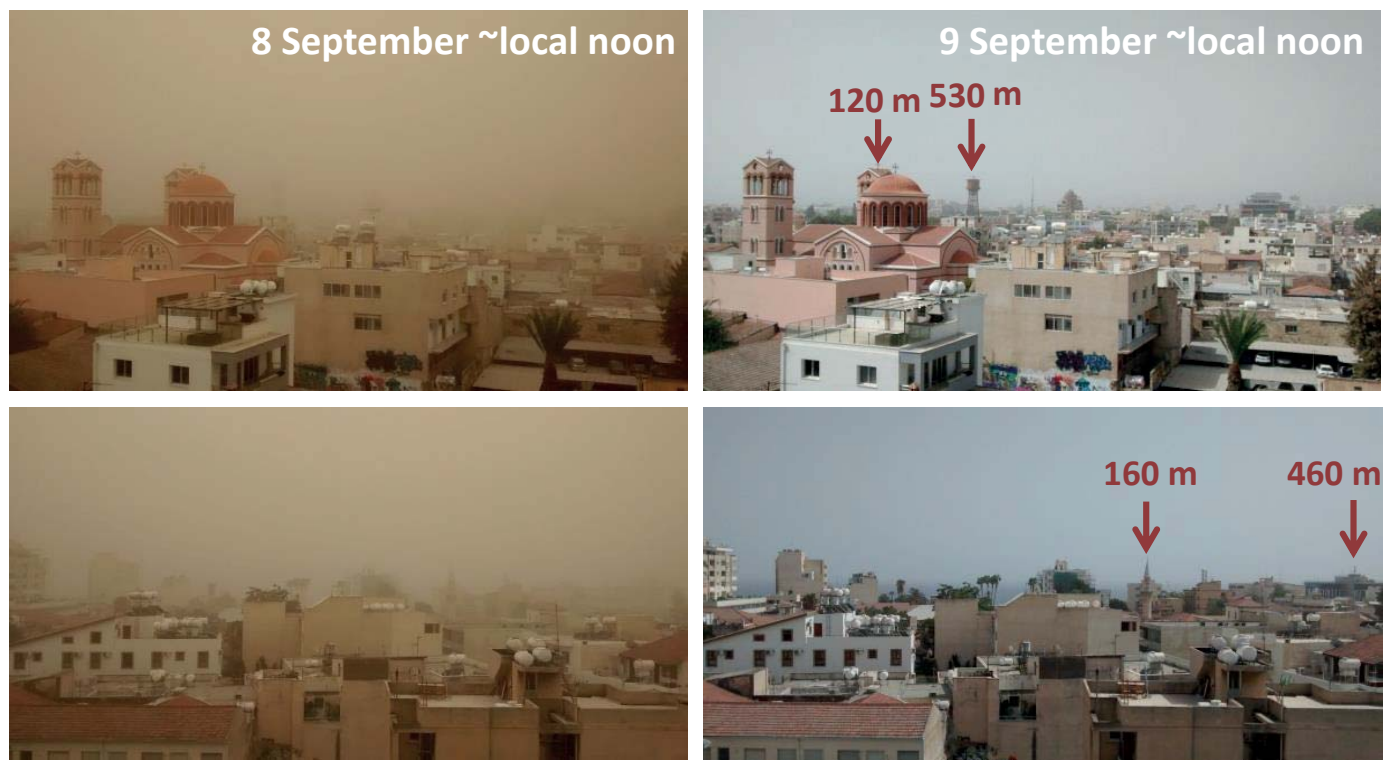

Figure 6. Photographs taken from the roof of a high building (CUT-TEPAK AERONET site) in the city center of Limassol to the north (top) and south (bottom) on 8 September 2015, 08:20-08:30 UTC (left) and on 9 September 2015 (right), again around local noon. The meteorological optical range (or horizontal visibility) was about $500 \mathrm{~m}$ on 8 September and $\geq 10 \mathrm{~km}$ on 9 September 2015 . Distances to several towers from the AERONET station are indicated.

dicated by the biased MODIS observations. Such huge dust optical depths indicate column dust loads of $8-15 \mathrm{~g} \mathrm{~m}^{-2}$. In the upper layer (above $1.5 \mathrm{~km}$ height), the AOT was significantly lower with values around 0.5 or less, as the lidar observations on 7 and 9-11 September indicate. This is consistent with the fact that the higher parts of the Troodos Mountains always remained visible, even on 8 September in Fig. 2.

Figure 5 also shows height profiles of the dust outbreaks simulated with the RAMS-ICLAMS model (Regional Atmospheric Modeling System/Integrated Community Limited Area Modeling System) (Cotton et al., 2003; Solomos et al., 2011). Details of these simulations are given in the followup paper (Solomos et al., 2016). Dust profiles for arrival times on the evening of 7 September and at local noon on 8 September 2015 are shown. The regional model (simulation with $20 \mathrm{~km}$ horizontal resolution) clearly underestimates the dust load. As explained in detail by Solomos et al. (2016) the event seems to be the result of two meteorological processes. A thermal low formed over Syria on 6 September 2015 associated with strong cloud convection and provided favorable conditions for the generation of a haboob along the borders between Iraq, Iran, Turkey, and Syria on 7 September 2015. Atmospheric density currents evolved and propagated towards the Mediterranean and pushed the pre-existing elevated dust layers towards the Mediterranean Sea. Furthermore, changes in land use and surface characteristics associated with the civil war in Syria and with other political conflicts in that region may have provided favorable conditions for strong dust emissions (Solomos et al., 2016). The main reasons that most dust prediction models (including RAMS in regional modeling configuration with horizontal resolution too low to resolve cloud convection processes) did not capture this episode are possibly related to the lack of sufficient physics packages to describe the feedback of clouds on dust mobilization and the lack of sufficient (cloud resolving) model resolution. A detailed discussion is given in the follow-up study (Solomos et al., 2016).

\subsection{Surface and profile observations of dust optical properties and mass concentrations}

Figure 7a shows time series of AOT retrieved from daily MODIS observations for four coastal sites from Rizokarpaso at the most eastern tip of Cyprus to Paphos, which is approximately $250 \mathrm{~km}$ southwest of Rizokarpaso. In addition, the AOT time series for the capital city Nicosia are shown. The mean AOT values for areas within a $50 \mathrm{~km}$ radius around the cities are presented. The maximum retrievable AOT is 5.0. As mentioned in Sect. 2.2, many of the individual, validated (pixel) AOT values were set to 5.0 (indicating that the true values were larger). For Fig 7, we used all validated data points in the averaging. Therefore, all area mean AOT values for 8 September (Julian day 251) exceeding 3.0 have to be interpreted with caution. They include many 5.0 AOT data and are thus biased (towards low AOT). As outlined in the preceding section, the uncertainty in the retrievable AOT values is about $0.05 \pm 0.15 \times$ AOT for $\mathrm{AOT} \leq 1.0$. A systematic overestimation of the order of 1.0 must be taken into account for high AOT $\geq 2.5$. 

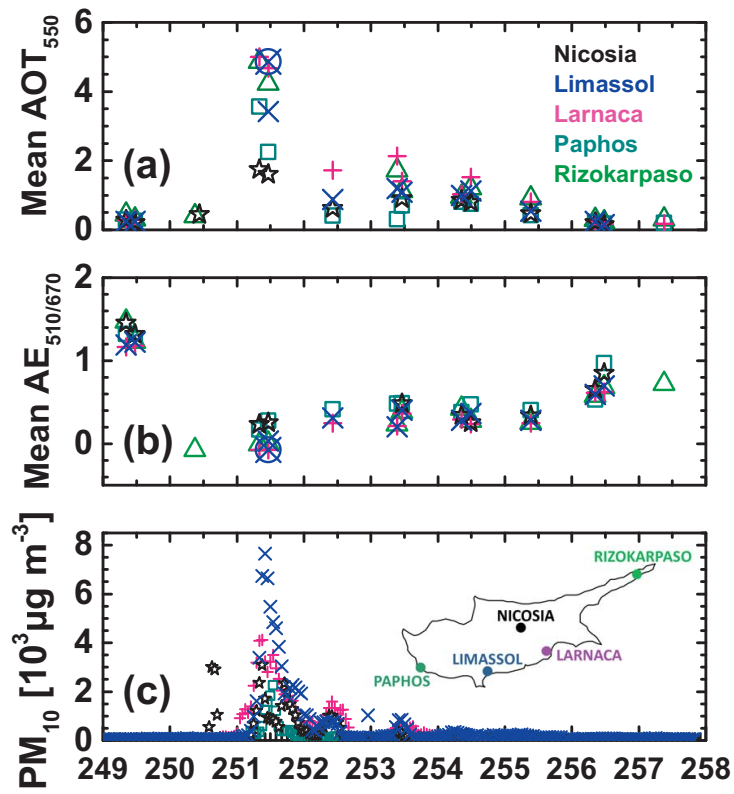

Julian day

Figure 7. (a) MODIS-derived mean $550 \mathrm{~nm}$ aerosol optical thickness (AOT) for five sites in Cyprus for the period from 6 to 14 September 2015 (Nicosia, stars; Limassol, diagonal crosses; Larnaca, crosses; Paphos, squares; Rizokarpaso, triangles; aquaMODIS, 10:30-11:30 UTC, and terra-MODIS, 08:00-09:00 UTC overpasses), (b) MODIS-derived Ångström exponent (for the 510$670 \mathrm{~nm}$ wavelength range), and (c) hourly mean $\mathrm{PM}_{10}$ particle mass concentrations measured at four stations in Cyprus (Nicosia, Limassol, Paphos, Larnaca). The AOTs are determined from all MODIS values in areas within a $50 \mathrm{~km}$ radius around a given city, except the AOT indicated by the blue diagonal cross with a circle (Limassol, $25 \mathrm{~km}$ radius, day 251 ).

The AOT clearly exceeded 4.0 in the eastern and southern parts of Cyprus on 8 September 2015, if we assume an AOT overestimation of 1.0. For Limassol, we also calculated the mean AOT of the area within a $25 \mathrm{~km}$ radius around $\mathrm{Li}$ massol on 8 September (blue diagonal cross with circle in Fig. 7). Again, the area mean AOT of 4.9 includes many 5.0 values, which indicate that the retrieved MODIS AOT clearly exceeded 5.0 over the EARLINET lidar station. It should be mentioned here that the mean AOT values were widely determined by the quality-assured values over the Mediterranean Sea (at all 5.0). Over land, the validated AOT values were significantly lower, mostly $3.0-3.5$ on 8 September, 10:30-11:30 UTC. However, over the orographically inhomogeneous terrain, north of the coastal city of Limassol (with surface levels mostly varying between 200 and more than $700 \mathrm{~m}$ height a.s.1.), quality-assured data were rare.

According to MODIS, the AOT ranged from 0.85 to 1.7 on 9 September 2015, 1.2-2.1 on 10 September, and 1.1-1.4 on 11 September over southern Cyprus (Fig. 7a, Larnaca, Limassol). The AOT was considerably lower at Paphos on 9-10
September, $70 \mathrm{~km}$ west of Limassol, with values of 0.4 and 0.3-0.7. In comparison, our lidar observations (taken about $6-11 \mathrm{~h}$ after the daily MODIS observations) indicate AOTs of 0.5-0.6 on 9 September (MODIS; Limassol, 0.85; Paphos, $0.4), 0.7-0.75$ on 10 September (MODIS; Limassol 1.2; Paphos, 0.3-0.7), and around 0.85 on 11 September (MODIS; Limassol, 1.1; Paphos, 0.8). Our lidar observations on 7 and 9-10 September reveal that the AOT contribution of the second layer above $1.5 \mathrm{~km}$ height was always of the order of 0.5 .

On 12 September 2015, all three stations showed significantly reduced dust loads with AOT values from 0.3 to 0.8 derived from the MODIS observations. In this context it should be mentioned that the relative humidity was always $<30,<40$, and $<50 \%$ within the lowermost one kilometer, up to the top of the lower dust layer, and up to the top of the upper dust layer, respectively, according to the Nicosia radiosonde launched on 7-11 September, so that effects of aerosol particle growth by water uptake on the observed AOT values can be neglected. The impact of anthropogenic particles and marine particles on the total AOT at $550 \mathrm{~nm}$ may have been of the order of $0.05-0.15$ and $0.03-0.05$, respectively (Nisantzi et al., 2015; Mamouri and Ansmann, 2014).

Figure 7b shows that the Ångström exponent (AE), which describes the wavelength dependence of AOT (for the visible wavelength range from 510 to $670 \mathrm{~nm}$ ), dropped from typical values of 1.0-1.5 for mixtures of anthropogenic aerosol and marine particles (and some local dust) to values around 0.3 during the dust period (ignoring the low $\mathrm{AE}$ values around 0 on 8 September, which are mostly based on biased AOT values).

Figure $7 \mathrm{c}$ presents the surface observations of $\mathrm{PM}_{10}$ concentrations from 6 to 14 September 2015. Hourly mean values for five sites across Cyprus are shown. Uncertainties are of the order of $\pm 50 \%$ for the sites of Larnaca, Limassol, and Paphos on 8 September 2015, and reduced to about $20 \%$ later on 9-11 September according to the uncertainty analysis described in Sect. 2.3. The maximum hourly mean dust mass concentration at Limassol was close to $8000 \mu \mathrm{g} \mathrm{m}^{-3}$ on 8 September. Note that the $\mathrm{PM}_{10}$ concentration was only $1300 \mu \mathrm{g} \mathrm{m}^{-3}$ on 1 April 2013 (second largest dust storm during the last 15 years over Limassol in Fig. 1) because Saharan dust layers crossed Cyprus and Saharan dust is mainly transported within lofted layers, as our EARLINET lidar observations show. The quality-assured daily mean values were $2900 \mathrm{\mu g} \mathrm{m}^{-3}$ (Larnaca), $1500 \mu \mathrm{g} \mathrm{m}^{-3}$ (Limassol), and $500 \mathrm{\mu g} \mathrm{m}^{-3}$ (Paphos) on 8 September, 2015.

The $\mathrm{PM}_{10}$ observations, which only consider particles with diameters $<10 \mu \mathrm{m}$, may have underestimated the total suspended particle (TSP) mass concentration. Kandler et al. (2009) showed that the TSP mass concentration can be an order or even two orders of magnitude larger than the respective $\mathrm{PM}_{10}$ value during haze periods and when density currentinduced dust fronts cross the field site. At Cabo Verde, after long range transport of dust over $1000-3000 \mathrm{~km}$, the TSPto- $\mathrm{PM}_{10}$ particle mass concentration ratio was found to be 

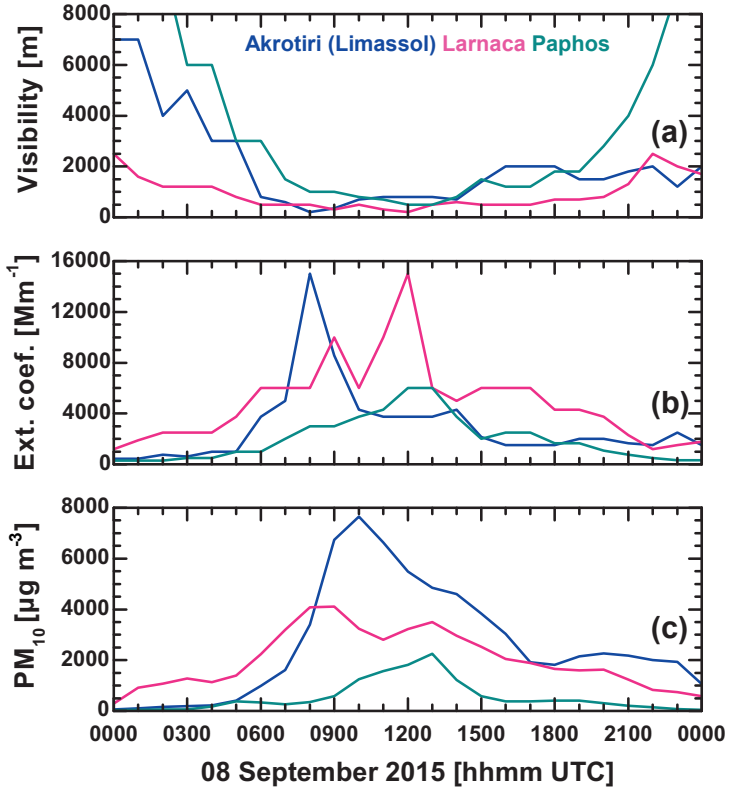

Figure 8. Visibility ( $r_{\text {vis }}$ in Eq. (2)) measured at three airports in southern Cyprus (see map in Fig. 7c) on 8 September 2015, (b) corresponding dust extinction coefficient (by using Eq. 2), and (c) $\mathrm{PM}_{10}$ concentrations (same as shown in Fig. 7c). Relative uncertainties in all parameters are of the order of $50 \%$. Dust extinction coefficients of $4000-8000 \mathrm{Mm}^{-1}$ indicate dust mass concentrations of $6600-13300 \mu \mathrm{g} \mathrm{m}^{-3}$.

mostly between 1.2 and 1.5 (Kandler et al., 2011). The visibility of $500 \mathrm{~m}$, according to Fig. 6, is related to a peak particle extinction coefficient of $6000 \mathrm{Mm}^{-1}$ and correspondingly to a peak TSP mass concentration of $10000 \mu \mathrm{g} \mathrm{m}^{-3}$. This peak TSP value is about a factor of 1.25-1.3 higher than the in situ measured maximum hourly mean $\mathrm{PM}_{10}$ value of around $7600 \mu \mathrm{g} \mathrm{m}^{-3}$, and thus in good agreement with Kandler et al. (2011).

To further check to what extent the $\mathrm{PM}_{10}$ dust observations underestimated the TSP mass concentration during these extreme dust conditions on 8 September 2015, we analyzed visibility observations at three airports in southern Cyprus. According to Eq. (2) in Sect. 2.4, the visibility is directly related to the particle extinction coefficient, which in turn is highly correlated with the particle volume and mass concentration. The relative uncertainty in the derived mass concentration is estimated to be about $30-40 \%$, provided the visibility is available, with an uncertainty of $20-30 \%$.

Figure 8 shows time series of visibility and corresponding extinction coefficient. All three stations show visibilities in the range 200-750 $\mathrm{m}$ from 05:00 to 20:00 (Larnaca), 6:00 to 14:00 (Limassol), and 10:00 to 14:00 UTC (Paphos). The lowest visibilities of $200-300 \mathrm{~m}$ values in the Limassol area were observed at Akrotiri airport (about $10 \mathrm{~km}$ southwest of the Limassol lidar station) from 08:00 to 09:00 UTC, when the photographs in Fig. 6 were taken. The corresponding par- ticle extinction and mass concentration values for Akrotiri are $9000-15000 \mathrm{Mm}^{-1}$ and $15000-25000 \mu \mathrm{g} \mathrm{m}^{-3}$, respectively. As mentioned in Sect. 2.4, marine and anthropogenic haze may have contributed to the total aerosol extinction coefficient by about $100-200 \mathrm{Mm}^{-1}$, so that their contribution to observed extinction values exceeding 2000 or $3000 \mathrm{Mm}^{-1}$ can be ignored in the following discussion and retrievals.

However, if we compare the quality-assured daily mean in situ measured $\mathrm{PM}_{10}$ values for Larnaca $\left(2900 \mu \mathrm{g} \mathrm{m}^{-3}\right)$, Limassol $\left(1500 \mu \mathrm{g} \mathrm{m}^{-3}\right)$, and Paphos $\left(500 \mu \mathrm{g} \mathrm{m}^{-3}\right)$ on 8 September 2015, with the respective daily mean TSP mass concentrations (calculated from MOR values measured every hour), we find visibility-related daily mean TSP mass concentrations of $7200 \mu \mathrm{g} \mathrm{m}^{-3}$ (Larnaca), $4150 \mu \mathrm{g} \mathrm{m}^{-3}$ (Akrotiri, Limassol), and $3200 \mu \mathrm{g} \mathrm{m}^{-3}$ (Paphos), which are a factor of 2.5 (Larnaca), 2.8 (Limassol), and 6.4 (Paphos) higher than the in situ measured $\mathrm{PM}_{10}$ daily means. These very high (and, in our opinion, unrealistic) factors of 2.56.4 may be caused by a wrong volume-to-extinction conversion factor $c_{\mathrm{v}, \mathrm{d}}=v_{\mathrm{d}} / \sigma_{\mathrm{d}}$ (a factor of 2 too high for Larnaca and Limassol) in Eq. (3), or by wrong visibility estimations (leading to a factor of 2 too low $r_{\mathrm{vis}}$ values) at these unusual dust conditions. The volume-to-extinction conversion factor is $0.64 \times 10^{-12} \mathrm{Mm}$ (as discussed in Sect. 2.1). A value around $0.32 \times 10^{-12} \mathrm{Mm}$ points to conditions with dominating fine-mode dust (Mamouri and Ansmann, 2016). At strong dust outbreak conditions we expect the opposite, namely that coarse mode dust particles dominate the measured optical effects so that the applied volume-to-extinction conversion factor of $0.64 \times 10^{-12} \mathrm{Mm}$ is appropriate. Therefore, we conclude that the visibility observations revealed too-low MOR values on 8 September 2015.

The next days showed steadily decreasing near-surface dust mass concentrations. The daily mean $\mathrm{PM}_{10}$ mass concentration decreased from $2900 \mu \mathrm{g} \mathrm{m}^{-3}$ (8 September) to 1000,500 , and $200 \mu \mathrm{g} \mathrm{m}^{-3}$ on the following days (911 September) at Larnaca, and from $1500 \mu \mathrm{g} \mathrm{m}^{-3}$ (8 September) to 500,200 , and $200 \mu \mathrm{g} \mathrm{m}^{-3}$ at Limassol on 911 September. This steady decrease of the near-surface dust mass concentration was not observed for the total column (see discussion of MODIS and lidar-derived AOTs above), which remained almost constant from 9 to 11 September.

The highlight of the observations are our lidar measurements of the vertical layering of the dust particles. Such profile observations are indispensable in the verification of modeling results and the reliability of model-based dust outbreak studies as a whole. Figure 4 provides an overview of the main dust layering features and mainly indicates a double layer structure of the advected dust plumes which point to two different air mass transport regimes and thus two dust source regions.

In Fig. 9, profiles of particle backscatter and extinction coefficients at $532 \mathrm{~nm}$, the corresponding extinction-tobackscatter ratio (lidar ratio), and the particle linear depolarization ratio at $532 \mathrm{~nm}$ for each of the four evenings on 7 and 

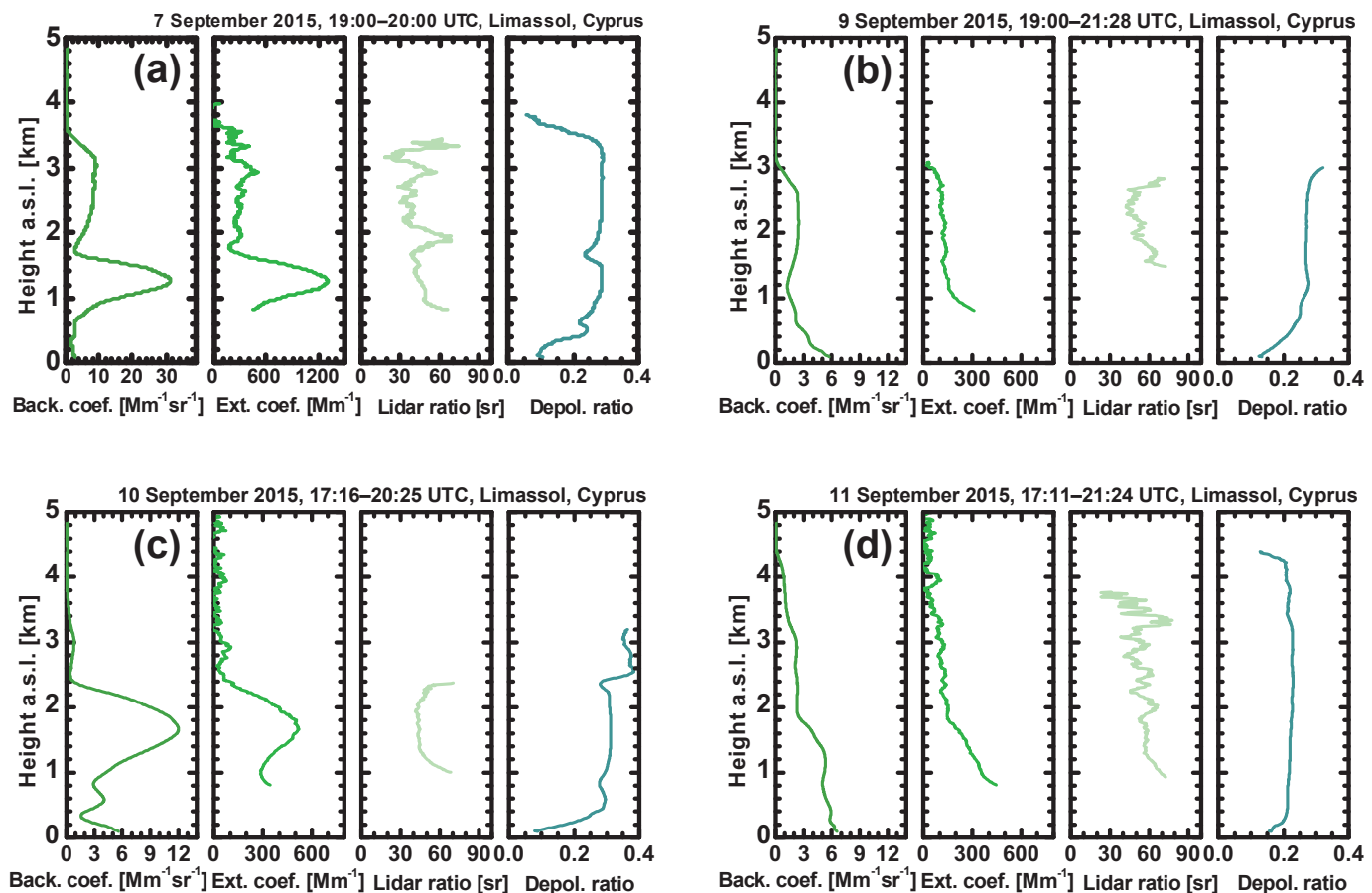

Figure 9. Mean vertical profiles of the $532 \mathrm{~nm}$ particle backscatter coefficient, extinction coefficient, lidar ratio, and particle linear depolarization ratio for the observational periods, given on top of the panels, on 7-11 September 2015. The Raman lidar method is applied. Retrieval uncertainties are of the order of $10 \%$ (backscatter coefficient, depolarization ratio) and of $20 \%$ (extinction coefficient, lidar ratio) at dense dust conditions.

9-11 September are given. 1-h to 3-h mean profiles provide an overview of the main features of the dust optical properties. The backscatter coefficients are obtained with high vertical resolution (signal smoothing window length of $195 \mathrm{~m}$ ) and show the layer structures best. The profiles of the particle backscatter coefficient and the particle linear depolarization ratio are trustworthy down to $100 \mathrm{~m}$ above ground, as comparison with the surface in situ observations $\left(\mathrm{PM}_{10}\right.$ measurements, visibility/extinction observations) corroborate, which will be discussed below. The extinction coefficients and corresponding lidar ratios are calculated from smoothed Raman signal profiles ( $375 \mathrm{~m}$ smoothing length).

The particle extinction coefficients reached values of $1300 \mathrm{Mm}^{-1}$ in the lower layer and were around $350 \mathrm{Mm}^{-1}$ in the second layer on 7 September. Another pronounced dust front caused extinction coefficients of up to $550 \mathrm{Mm}^{-1}$ in an elevated layer between 1000 and $2500 \mathrm{~m}$ height on 10 September 2015. The lidar ratios at $532 \mathrm{~nm}$ were 35$42 \mathrm{sr}$ in the dust layers on 7 and 10 September, 45-60 sr on 9 September, and 50-60 sr on 11 September. Values of 35$45 \mathrm{sr}$ are typical for desert dust from Middle Eastern dust sources (Mamouri et al., 2013; Nisantzi et al., 2015). Larger lidar ratios on 9 and 11 September indicate a mixture of dust and anthropogenic haze.

The particle linear depolarization ratio assumed typical dust values of $0.25-0.32$ ( 7 and 10 September) in the dense dust layers. These values clearly indicate the dominance of mineral dust in these layers. The decrease towards values of $0.20-0.25$ on 9 and 11 September reflects the increasing impact of anthropogenic haze on the optical properties of the advected air masses. The linear depolarization ratio dropped to values clearly below 0.2 in the lowermost $300-500 \mathrm{~m}$ thick marine boundary layer over Limassol and was around 0.10.15 at $100 \mathrm{~m}$ above ground on 9-10 September. Such low depolarization ratios indicate that anthropogenic pollution contributed to more than $50 \%$ of the overall total particle backscattering and extinction coefficients and to $30-50 \%$ of the particle mass concentration in the city on 9-10 September.

The backscatter and extinction profiles and the lidar ratio information allow us to estimate the $532 \mathrm{~nm}$ AOT. We estimated the extinction values in the vertical range without extinction measurements (in the lowermost about $800 \mathrm{~m}$ ) by multiplying the backscatter coefficients with a lidar ratio of $50 \mathrm{sr}$, which is higher than a pure-dust lidar ratio and takes the influence of anthropogenic pollution (lidar ratios of 60-80 sr) into account. On 7 September, the $532 \mathrm{~nm}$ AOT for the lower layer ( $0-1.7 \mathrm{~km}$ height) was 1.2 and 0.5 for the upper layer from 1.7 to $3.5 \mathrm{~km}$, according to the evening lidar observations. Comparison with MODIS observations before and after noon is not possible on this day because of the rapidly changing dust conditions.

On 9 September, the $532 \mathrm{~nm}$ AOT greatly decreased from the record-breaking values $>5.0$ on 8 September to values 


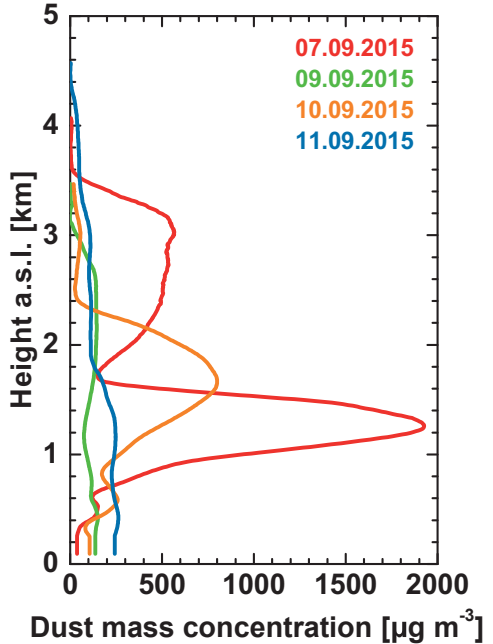

Figure 10. Lidar-derived mean dust mass concentrations for the evening periods (see Fig. 9) of 7 September (19:0020:00 UTC), 9 September (19:00-21:28 UTC), 10 September (17:16-20:25 UTC), and 11 September (17:11-21:25 UTC). The overall uncertainty in the retrieval of the dust mass concentration is of the order of $25 \%$.

of 0.55 , with an AOT around 0.35 for the lowermost $1.2 \mathrm{~km}$ height region and 0.2 for the upper dust layer from 1.2 to $3.0 \mathrm{~km}$ in height. In contrast to the evening lidar observations, the morning MODIS data still revealed an AOT of $0.8-1.0$ on 9 September.

Another dense dust outbreak plume reached Cyprus on 10 September. The daytime AOT (MODIS) for Limassol showed a slight increase to 1.0-1.2, while the lidar observed an overall AOT of $0.7-0.8$ (as $3 \mathrm{~h}$ average) in late evening on 10 September 2015. The lower dust layer (up to $1 \mathrm{~km}$ height) contributed about $0.2-0.3$ and the upper layer (1$3 \mathrm{~km}$ ) around 0.5 to the total AOT. More vertically homogeneous dust backscatter and extinction profiles were observed on 11 September, with an AOT of around 0.6 for the lower part (0-1.8 km height) of the dust layer and an AOT of about 0.25 for the upper part from 1.8 to $4.2 \mathrm{~km}$ height. MODIS AOT values on 11 September were still around 1.0 (for all stations Larnaca, Limassol, Paphos). Thus, a good agreement between MODIS and lidar observations was found for the final day of the dust storm.

We also studied to what extent the lidar backscatter coefficients and the estimated extinction values close to the ground are reliable. Visibility observations yield values for the meteorological optical range of around $10 \mathrm{~km}$ on the evening of 9 September, which corresponds to particle extinction coefficients of about $300 \mathrm{Mm}^{-1}$. The lidar measurements indicate backscatter coefficients of $6 \mathrm{Mm}^{-1} \mathrm{sr}^{-1}$ close to the surface on 9 September, and thus extinction coefficients of $275 \mathrm{Mm}^{-1}$ (by multiplying the backscatter coefficient with a lidar ratio of $45 \mathrm{sr}$, representing dust-dominated conditions) to $330 \mathrm{Mm}^{-1}$ (for a lidar ratio of $55 \mathrm{sr}$, representing a mixture of dust and urban haze).

An overview of the vertical dust mass distribution, observed on the evenings of 7, 9, 10, and 11 September 2015, is given in Fig. 10. In Eq. (1), we used a typical Middle Eastern lidar ratio of $40 \mathrm{sr}$ (Mamouri et al., 2013). After the first very dense dust plumes on 7-8 September, another dense dust plume crossed Limassol on the evening of 10 September, as mentioned, and the dust mass concentrations were again high, with values close to $800 \mu \mathrm{g} \mathrm{m}^{-3}$ in the center of the elevated layer from 1000 to $2500 \mathrm{~m}$ height. The double layer structure vanished on 11 September. Only one layer extending from the surface up to $4.2 \mathrm{~km}$ height was observed. In terms of column dust mass concentrations we obtained values of $1.9 \mathrm{~g} \mathrm{~m}^{-2}$ (for 7 September in Fig. 10), $0.35 \mathrm{~g} \mathrm{~m}^{-2}$ (9 September), $0.95 \mathrm{~g} \mathrm{~m}^{-2}$ (10 September), and $0.6 \mathrm{~g} \mathrm{~m}^{-2}$ (11 September). AOTs of 4.8-9, as estimated for the peak dust front on 8 September, indicate peak column dust loads of $8-15 \mathrm{~g} \mathrm{~m}^{-2}$.

Regarding the quality of the lidar-derived TSP mass concentrations close to the ground, we compared the lidar data with respective $\mathrm{PM}_{10}$ observations (mean values for the lidar measurement periods in Fig. 10). The Limassol evening $\mathrm{PM}_{10}$ values (considering dust and aerosol pollution) were $55 \mu \mathrm{g} \mathrm{m}^{-3}$ (7 September), $120 \mu \mathrm{g} \mathrm{m}^{-3}$ (9 September), $125 \mu \mathrm{g} \mathrm{m}^{-3}$ (10 September), and $165 \mu \mathrm{g} \mathrm{m}^{-3}$ (11 September). The respective lidar-derived total aerosol mass concentrations were $65 \mathrm{\mu g} \mathrm{m}^{-3}$ (7 September), $180 \mu \mathrm{g} \mathrm{m}^{-3}$ (9 September), $125 \mu \mathrm{g} \mathrm{m}^{-3}$ (10 September), and $290 \mu \mathrm{g} \mathrm{m}^{-3}$ (11 September). The uncertainties are roughly $30 \%$ for the lidar mass values and $50 \%$ for hourly mean $\mathrm{PM}_{10}$ values. Again, good agreement is obtained taking the uncertainties in the derived values into account. Horizontally inhomogeneous downward mixing of dust and horizontal inhomogeneities in the mixture of dust and urban pollution may have also contributed to the differences. Note that Fig. 10 only shows the dust-related mass concentrations. The contribution of urban and marine aerosol to the TSP mass concentration was of the order of $20-30 \mu^{-3} \mathrm{~m}^{-3}$ (7 and 10 September) and 40 $50 \mu \mathrm{g} \mathrm{m}^{-3}$ (9 and 11 September 2015).

\section{Conclusions}

A record-breaking dust storm over the eastern Mediterranean in September 2015 has been documented and discussed based on satellite, lidar, and in situ aerosol observations in the Cyprus area. We were able to provide a consistent picture of this dust event in terms of a variety of optical, microphysical, and dust layering properties obtained by means of very different in situ and remote sensing observational techniques and retrieval approaches. The presented documentation of an extreme dust storm is a valuable contribution to the literature dealing with long-range transport of dust, forecasting of dust 
outbreaks, and research on the relationship between meteorological conditions and dust emission intensity.

Such unique events may take place once in a decade or even less frequently and are thus obviously linked to unique meteorological conditions. The documentation of extremely rare dust storms with vertical, horizontal, and temporal resolution (in this article) in combination with advanced atmospheric modeling covering cloud evolution, development of thunderstorms, density currents, dust mobilization, and dust transport (in the follow-up article) will certainly lead to an improved understanding of the evolution of dust storms at extreme meteorological conditions. The modeling studies will further reveal what kind of modeling infrastructure is required to resolve even small-scale hot spots of dust mobilization phenomena in order to improve dust forecasting in general.

Another concluding remark deals with the need of a dust lidar network around the main desert areas, e.g., in the Europe-Africa-Asia region around the Sahara, over the Middle East deserts to the desert regions in central, southern, and eastern Asia. Continuously operated lidars would be an ideal supplement to dust forecast model efforts, with the potential goal to assimilate the lidar products into the forecast models. As demonstrated in this article, modern polarization lidars allow us to separate dust and non dust optical properties and to quantify the dust-related particle extinction coefficient and mass concentration in the vertical profile with an uncertainty of $20-30 \%$.

\section{Data availability}

The terra and aqua MODIS aerosol data are accessible at http://lance-modis.eosdis.nasa.gov/ and https://ladsweb. nascom.nasa.gov/ (MODIS, 2016). AERONET data are available at http://aeronet.gsfc.nasa.gov/ (AERONET, 2016), surface mass concentrations (Department of Labour Inspection, Republic of Cyprus) at http://www.airquality.dli.mlsi. gov.cy/ (Department of Labour Inspection, Cyprus, 2016), and radiosonde data at http://weather.uwyo.edu/upperair/ sounding.html (Wyoming Weather Web, 2016). Lidar profiles can be downloaded from the ACTRIS data base at http://actris.nilu.no (ACTRIS/EARLINET, 2016).

Acknowledgements. The authors thank the Eratosthenes Research Center of CUT for support. Rodanthi-Elisavet Mamouri would like to thank CUT's library for the financial support within the Cyprus University of Technology Open Access Author Fund. The authors acknowledge support from the following projects and research programs: ACTRIS Research Infrastructure (EU H2020-R\&I) under grant agreement no. 654169, BEYOND (Building Capacity for a Centre of Excellence for EO-based Monitoring of Natural Disasters, FP7-REGPOT-2012-2013-1) under grant agreement no. 316210, BACCHUS (impact of Biogenic vs. Anthropogenic emissions on Clouds and Climate: Towards a Holistic Understanding, EU FP7-ENV-2013) under grant agreement project number 603445, and GEO-CRADLE (EU H2020 R\&I) under grant agreement No 690133. The authors are very thankful to the Air Quality Department (Department of Labour Inspection, DLI) for establishing and maintaining the air quality stations of Republic of Cyprus, and Chrysanthos Savvides (DLI) for providing qualityassured $\mathrm{PM}_{10}$ daily means. We further thank Filippos Tymvios from the Department of Meteorology (DoM) of Cyprus for the visibility observations. The authors are grateful to AERONET for high-quality sun/sky photometer measurements. We gratefully acknowledge the NOAA Air Resources Laboratory (ARL) for the provision of the HYSPLIT transport and dispersion model as well for the provision of Global Data Assimilation System (GDAS) data used in this publication. We acknowledge the use of data products or imagery from the Land Atmosphere Near real-time Capability for EOS (LANCE) system operated by the NASA/GSFC/Earth Science Data and Information System (ESDIS) with funding provided by NASA/HQ.

Edited by: M. Tesche

Reviewed by: four anonymous referees

\section{References}

ACTRIS/EARLINET: EARLINET aerosol lidar profiles, available at: http://actris.nilu.no, last access: October, 2016.

AERONET: AERONET aerosol data base, available at: http:// aeronet.gsfc.nasa.gov/, last access: October, 2016.

Amiridis V., Balis, D., Kazadzis, S., Giannakaki, E., Papayannis, A., and Zerefos, C.: Four years aerosol observations with a Raman lidar at Thessaloniki, Greece, in the framework of European Aerosol Research Lidar Network (EARLINET), J. Geophys. Res., 110, D21203, doi:10.1029/2005JD006190, 2005.

Ansmann, A., Tesche, M., Seifert P, Groß, S., Freudenthaler, V., Apituley, A., Wilson, K. M., Serikov, I., Linné, H., Heinold, B., Hiebsch, A., Schnell, F., Schmidt, J., Mattis, I., Wandinger, U., and Wiegner, M.: Ash and fine-mode particle mass profiles from EARLINET-AERONET observations over central Europe after the eruptions of the Eyjafjallajökull volcano in 2010, J. Geophys. Res., 116, D00U02, doi:10.1029/2010JD015567, 2011.

Ansmann, A., Seifert, P., Tesche, M., and Wandinger, U.: Profiling of fine and coarse particle mass: case studies of Saharan dust and Eyjafjallajökull/Grimsvötn volcanic plumes, Atmos. Chem. Phys., 12, 9399-9415, doi:10.5194/acp-12-9399-2012, 2012.

Cotton, W. R., Pielke Sr., R. A., Walko, R. L., Liston, G. E., Tremback, C. J., Jiang, H., McAnelly, R. L., Harrington, J. Y., Nicholls, M. E., Carrio, G. G., and McFadden, J. P.: RAMS 2001: Current status and future directions, Meteor. Atmos. Phys., 82, 5-29, 2003

Department of Labour Inspection, Cyprus: Surface particle mass concentrations, available at: http://www.airquality.dli.mlsi.gov. cy/, last access: October, 2016.

Gasteiger, J., Wiegner, M., Groß, S., Freudenthaler, V., Toledano, C., Tesche, M., and Kandler, K.: Modeling lidar-relevant optical properties of complex mineral dust aerosols, Tellus B, 63, 725741, doi:10.1111/j.1600-0889.2011.00559.x, 2011a.

Gasteiger, J., Groß, S., Freudenthaler, V., and Wiegner, M.: Volcanic ash from Iceland over Munich: mass concentration retrieved from ground-based remote sensing measurements, At- 
mos. Chem. Phys., 11, 2209-2223, doi:10.5194/acp-11-22092011, 2011b.

Georgoulias, A. K., Alexandri, G., Kourtidis, K. A., Lelieveld, J., Zanis, P., Pöschl, U., Levy, R., Amiridis, V., Marinou, E., and Tsikerdekis, A.: Spatiotemporal variability and contribution of different aerosol types to the Aerosol Optical Depth over the Eastern Mediterranean, Atmos. Chem. Phys. Discuss., doi:10.5194/acp-2016-401, in review, 2016.

Gkikas, A., Basart, S., Hatzianastassiou, N., Marinou, E., Amiridis, V., Kazadzis, S., Pey, J., Querol, X., Jorba, O., Gassó, S., and Baldasano, J. M.: Mediterranean intense desert dust outbreaks and their vertical structure based on remote sensing data, Atmos. Chem. Phys., 16, 8609-8642, doi:10.5194/acp-16-86092016, 2016.

Guerrero-Rascado, J. L., Olmo, F. J., Avilés-Rodríguez, I., NavasGuzmán, F., Pérez-Ramírez, D., Lyamani, H., and Alados Arboledas, L.: Extreme Saharan dust event over the southern Iberian Peninsula in September 2007: active and passive remote sensing from surface and satellite, Atmos. Chem. Phys., 9, 84538469, doi:10.5194/acp-9-8453-2009, 2009.

Heinold, B., Tegen, I., Esselborn, M., Kandler, K., Knippertz, P., Müller, D., Schladitz, A., Tesche, M., Weinzierl, B., Ansmann, A., Althausen, D., Laurent, B., Massling, A., Müller, T., Petzold, A., Schepanski, K., and Wiedensohler, A.: Regional Saharan dust modelling during the SAMUM 2006 campaign, Tellus B, 61, 307-324, doi:10.1111/j.1600-0889.2008.00387.x, 2009

Heinold, B., Tegen, I., Schepanski, K., Tesche, M., Esselborn, M., Freudenthaler, V., Groß, S., Kandler, K., Knippertz, P., Müller D., Schladitz, A., Toledano, C., Weinzierl, B., Ansmann, A., Althausen, D., Müller, T., Petzold, A., and Wiedensohler, A.: Regional modelling of Saharan dust and biomass-burning smoke: Part I: Model description and evaluation, Tellus B, 63, 781-799, doi:10.1111/j.1600-0889.2011.00570.x, 2011.

Holben, B. N., Eck, T. F., Slutsker, I., Tanré, D., Buis, J. P., Setzer, A., Vermote, E., Reagan, J. A., Kaufman, Y. J., Nakajima, T., Lavenu, F., Jankowiak, I., and Smirnov, A.: AERONET - A federated instrument network and data archive for aerosol characterization, Remote Sens. Environ., 66, 1-16, 1998.

Horvath, H.: On the applicability of the Koschmieder visibility formula, Atmos. Environ, 5, 177-184, 1971.

Horvath, H. and Noll, K. E.: The relationship between atmospheric light scattering coefficient and visbility, Atmos. Environ., 3, $543-$ 550,1969

Kandler, K., Schütz, L., Deutscher, C., Ebert, M., Hofmann, H., Jäckel, S., Jaenicke, R., Knippertz, P., Lieke, K., Massling, A., Petzold, A., Schladitz, A., Weinzierl, B., Wiedensohler, A., Zorn, S., and Weinbruch, S.: Size distribution, mass concentration, chemical and mineralogical composition and derived optical parameters of the boundary layer aerosol at Tinfou, Morocco, during SAMUM 2006, Tellus B, 61, 32-50, doi:10.1111/j.16000889.2008.00385.x, 2009.

Kandler, K., Schütz, L., Jäckel, S., Lieke, K., Emmel, C., MüllerEbert, D., Ebert, M., Scheuvens, D., Schladitz, A., Segvić, B., Wiedensohler, A., and Weinbruch, S.: Ground-based offline aerosol measurements at Praia, Cape Verde, during the Saharan Mineral Dust Experiment: microphysical properties and mineralogy, Tellus B, 63, 459-474, doi:10.1111/j.16000889.2011.00546.x, 2011.
Knippertz, P., Deutscher, C., Kandler, K., Müller, T., Schulz, O. and Schütz L.: Dust mobilization due to density currents in the Atlas region. Observations from the Saharan Mineral Dust Experiment 2006 field campaign, J. Geophys. Res., 112, D21109, doi:10.1029/2007JD008774, 2007.

Koschmieder, H.: Theorie der horizontalen Sichtweite, Beiträge zur Physik der freien Atmosphäre, 12, 33-53, 1924.

Levy, R. C., Remer, L. A., Kleidman, R. G., Mattoo, S., Ichoku, C., Kahn, R., and Eck, T. F.: Global evaluation of the Collection 5 MODIS dark-target aerosol products over land, Atmos. Chem. Phys., 10, 10399-10420, doi:10.5194/acp-10-10399-2010, 2010.

Levy, R. C., Mattoo, S., Munchak, L. A., Remer, L. A., Sayer, A. M., Patadia, F., and Hsu, N. C.: The Collection 6 MODIS aerosol products over land and ocean, Atmos. Meas. Tech., 6, 29893034, doi:10.5194/amt-6-2989-2013, 2013.

Mamouri, R. E., Papayannis, A., Amiridis, V., Müller, D., Kokkalis, P., Rapsomanikis, S., Karageorgos, E. T., Tsaknakis, G., Nenes, A., Kazadzis, S., and Remoundaki, E.: Multi-wavelength Raman lidar, sun photometric and aircraft measurements in combination with inversion models for the estimation of the aerosol optical and physico-chemical properties over Athens, Greece, Atmos. Meas. Tech., 5, 1793-1808, doi:10.5194/amt-5-1793-2012, 2012.

Mamouri, R. E., Ansmann, A., Nisantzi, A., Kokkalis, P., Schwarz, A., and Hadjimitsis, D.: Low Arabian dust extinctionto-backscatter ratio, Geophys. Res. Lett., 40, 4762-4766, doi:10.1002/grl.50898, 2013.

Mamouri, R. E. and Ansmann, A.: Fine and coarse dust separation with polarization lidar, Atmos. Meas. Tech., 7, 3717-3735, doi:10.5194/amt-7-3717-2014, 2014.

Mamouri, R. E. and Ansmann, A.: Estimated desert-dust ice nuclei profiles from polarization lidar: methodology and case studies, Atmos. Chem. Phys., 15, 3463-3477, doi:10.5194/acp-15-34632015, 2015.

Mamouri, R. E. and Ansmann, A.: Fine and coarse dust separation with polarization lidar: Extended methodology for multiple wavelengths, to be submitted to Atmos. Meas. Tech. Discuss., 2016.

MODIS: MODIS aerosol retrievals, available at: http://lance-modis. eosdis.nasa.gov/ and https://ladsweb.nascom.nasa.gov/, last access: October, 2016.

Mona, L., Amodeo, A., Pandolfi, M., and Pappalardo, G.: Saharan dust intrusions in the Mediterranean area: Three years of Raman lidar measurements, J. Geophys. Res., 111, D16203, doi:10.1029/2005JD006569, 2006.

Mona, L., Papagiannopoulos, N., Basart, S., Baldasano, J., Binietoglou, I., Cornacchia, C., and Pappalardo, G.: EARLINET dust observations vs. BSC-DREAM8b modeled profiles: 12year-long systematic comparison at Potenza, Italy, Atmos. Chem. Phys., 14, 8781-8793, doi:10.5194/acp-14-8781-2014, 2014

Müller, D., Heinold, B., Tesche, M., Tegen, I., Althausen, D., Alados-Arboledas, L., Amiridis, V., Amodeo, A., Ansmann, A., Balis, D., Comerion, A., D'Amico, G., Gerasopoulos, E., Guerrero-Rascado, J. L., Freudenthaler, V., Giannakaki, E., Heese, B., Iarlori, M., Knippterz, P., Mamouri, R. E., Mona, L., Papayannis, A., Pappalardo, G., Perrone, R.-M., Pisani, G., Rizi, V., Sicard, M., Spinelli, N., Tafuro, A., and Wiegner, M.: EARLINET observations of the 14-22 May long-range dust transport event during SAMUM 2006: validation of results from dust 
transport modelling, Tellus B, 61, 325-339, doi:10.1111/j.16000889.2008.00400.x, 2009.

Nisantzi, A., Mamouri, R. E., Ansmann, A., and Hadjimitsis, D.: Injection of mineral dust into the free troposphere during fire events observed with polarization lidar at Limassol, Cyprus, Atmos. Chem. Phys., 14, 12155-12165, doi:10.5194/acp-1412155-2014, 2014.

Nisantzi, A., Mamouri, R. E., Ansmann, A., Schuster, G. L., and Hadjimitsis, D. G.: Middle East versus Saharan dust extinctionto-backscatter ratios, Atmos. Chem. Phys., 15, 7071-7084, doi:10.5194/acp-15-7071-2015, 2015.

Papayannis, A., Amiridis, V., Mona, L., Tsaknakis, G., Balis, D., Bösenberg, J., Chaikovski, A., De Tomasi, F., Grigorov, I., Mattis, I., Mitev, V., Müller, D., Nickovic, S., Pérez, C., Pietruczuk, A., Pisani, G., Ravetta, F., Rizi, V., Sicard, M., Trickl, T., Wiegner, M., Gerding, M., Mamouri, R. E., D’Amico, G., and Pappalardo, G.: Systematic lidar observations of Saharan dust over Europe in the frame of EARLINET (2000-2002), J. Geophys. Res., 113, D10204, doi:10.1029/2007JD009028, 2008.

Papayannis, A., Mamouri, R. E., Amiridis, V., Kazadzis, S., Pérez, C., Tsaknakis, G., Kokkalis, P., and Baldasano, J. M.: Systematic lidar observations of Saharan dust layers over Athens, Greece in the frame of EARLINET project (2004-2006), Ann. Geophys., 27, 3611-3620, doi:10.5194/angeo-27-3611-2009, 2009.

Pappalardo, G., Amodeo, A., Apituley, A., Comeron, A., Freudenthaler, V., Linné, H., Ansmann, A., Bösenberg, J., D’Amico, G., Mattis, I., Mona, L., Wandinger, U., Amiridis, V., AladosArboledas, L., Nicolae, D., and Wiegner, M.: EARLINET: towards an advanced sustainable European aerosol lidar network, Atmos. Meas. Tech., 7, 2389-2409, doi:10.5194/amt-7-23892014, 2014.

Preißler, J., Wagner, F., Pereira, S. N., and Guerrero-Rascado, J. L.: Multi-instrumental observation of an exceptionally strong Saharan dust outbreak over Portugal, J. Geophys. Res., 116, D24204, doi:10.1029/2011JD016527, 2011.
Solomos, S., Kallos, G., Kushta, J., Astitha, M., Tremback, C., Nenes, A., and Levin, Z.: An integrated modeling study on the effects of mineral dust and sea salt particles on clouds and precipitation, Atmos. Chem. Phys., 11, 873-892, doi:10.5194/acp11-873-2011, 2011.

Solomos, S., Kallos, G., Mavromatidis, E., and Kushta, J.: Density currents as a desert dust mobilization mechanism, Atmos. Chem. Phys., 12, 11199-11211, doi:10.5194/acp-12-11199-2012, 2012.

Solomos, S., Ansmann, A., Mamouri, R.-E., Binietoglou, I., Patlakas, P., Marinou, E., and Amiridis V., Remote sensing and modeling analysis of the extreme dust storm hitting the Middle East and eastern Mediterranean in September 2015, to be submitted to Atmos. Chem. Phys. Discuss., 2016.

Stein, A. F., Draxler, R. R., Rolph, G. D., Stunder, B. J. B., Cohen, M. D., and Ngan, F.: NOAA's HYSPLIT Atmospheric Transport and Dispersion Modeling System, B. Am. Meteorol. Soc., 96, 2059-2077, doi:10.1175/BAMS-D-14-00110.1, 2015

Tesche, M., Ansmann, A., Müller, D., Althausen, D., Mattis, I., Heese, B., Freudenthaler, V., Wiegner, M., Esselborn, M., Pisani, G., and Knippertz, P.: Vertical profiling of Saharan dust with Raman lidars and airborne HSRL in southern Morocco during SAMUM, Tellus B, 61, 144-164, doi:10.1111/j.16000889.2008.00390.x, 2009a.

Tesche, M., Ansmann, A., Müller, D., Althausen, D., Engelmann, R., Freudenthaler, V., and Groß, S.: Vertically resolved separation of dust and smoke over Cape Verde using multiwavelength Raman and polarization lidars during Saharan Mineral Dust Experiment 2008, J. Geophys. Res., 114, D13202, doi:10.1029/2009JD011862, 2009b.

Wyoming Weather Web: Radiosonde profiles of meteorological parameters, available at: http://weather.uwyo.edu/upperair/ sounding.html, last access: October, 2016. 